benoxaprofen damage was reduced; this may be due to a subclinical photosensitivity reaction, as occurs with onycholysis, which may not be associated with obvious sun sensitivity. It is not yet clear whether the hypertrichosis is simply secondary to the photosensitivity, as is seen in porphyria ${ }^{4}$ and when alopecia areata is treated with ultraviolet $B$ or psoralen-ultraviolet $A$, or whether a different mechanism is entailed, as in hypertrichosis associated with minoxidil. ${ }^{5}$

We thank Dr M Tobin and Dr W E B Preston for permission to report their cases.

${ }^{1}$ Mikulaschek WM. Longterm safety of benoxaprofen. $\mathcal{F}$ Rheumatol 1980; 7 , suppl 6: 100-7.

2 Taylor AEM, Goff D, Hindson TC. Association between StevensJohnson syndrome and benoxaprofen. $\mathrm{Br}$ Med $\mathcal{F} 1981 ; 282: 1433$.

${ }^{3}$ Fenton DA, English JS. Toxic epidermal necrolysis, leucopenia and thrombocytopenic purpura-a further complication of benoxaprofen therapy Clin Exp Dermatol (in press).

${ }^{4}$ Kaufman BM, Vickers HR, Rayne J, Ryan TJ. Congenital erythropoietic porphyria. Br f Dermatol 1967:79:210-20.

${ }_{5}^{5}$ Burton JL, Marshall A. Hypertrichosis due to minoxidil. Br $\mathcal{f}$ Dermatol $1979 ; 101$ :593-5.

(Accepted 20 January 1982)

Department of Dermatology, Wycombe General Hospital, High Wycombe, Buckinghamshire HP11 2TT

DAVID A FENTON, MB, MRCP, registrar in dermatology

JOHN S ENGLISH, MB, MRCP, senior house officer in dermatology

JOHN D WILKINSON, MB, MRCP, consultant dermatologist

\section{Haemophilus influenza type b resistant to both chloramphenicol and ampicillin in Britain}

It is now standard practice to treat severe infections due to Haemophilus influenzae with either chloramphenicol alone or a combination of ampicillin and chloramphenicol. We describe a patient who twice became infected with a strain of $H$ influenzae type $b$ that was resistant to both ampicillin and chloramphenicol.

\section{Case report}

A 9-year-old boy was diagnosed in 1979 as having dermatomyositis, which was treated with prednisolone with a satisfactory initial response. To reduce his dependency on steroids, salicylates, sodium etidronate, and penicillamine were introduced sequentially, starting in January 1981. In April a calcinotic lesion medial to the left knee became infected and discharged pus.

Routine swabs were taken and treatment started with flucloxacillin 50 $\mathrm{mg} / \mathrm{kg} 24$ hours and fusidic acid $20 \mathrm{mg} / \mathrm{kg} 24$ hours. Staphylococcus aureus sensitive to erythromycin, methicillin, gentamicin, co-trimoxazole, and cefuroxime but resistant to fusidic acid and penicillin, and $H$ influenzae sensitive to erythromycin, gentamicin, and cefuroxime but resistant to ampicillin and chloramphenicol were isolated. Flucloxacillin was therefore stopped and intravenous erythromycin started. This caused painful phlebitis, and cefuroxime $56 \mathrm{mg} / \mathrm{kg} /$ day was substituted two days later. Intravenous antibiotics were given for a total of nine days. Flucloxacillin $40 \mathrm{mg} / \mathrm{kg} / \mathrm{day}$ and cephalexin $40 \mathrm{mg} / \mathrm{kg} /$ day were given by mouth for a further 12 days. The treatment of his underlying dermatomyositis was then changed to daily highdose prednisolone and weekly methotrexate because of progressive muscular weakness.

Six weeks after stopping antibiotics he had a general anaesthetic for insertion of grommets and simultaneous plastic surgery to repair a persistent skin defect over the left knee. One week later he developed pneumonia with production of purulent sputum. Chest radiography showed no acute changes. Sputum samples grew $H$ influenzae, again resistant to ampicillin and chloramphenicol but sensitive to gentamicin. This was successfully treated with intravenous gentamicin and flucloxacillin. His general condition continued to deteriorate, however, and despite intensive treatment including plasmapheresis he died one month later.

Bacteriology-On both occasions the organism was initially identified as $H$ influenzae by its morphological appearance when cultured on blood and chocolate agar. This was confirmed by its nutritional requirements of haeme and diphosphopyridine nucleotide ( $\mathrm{X}$ and $\mathrm{V}$ factors). The isolate from the sputum was cultured on chocolate agar and then slide agglutination testing performed (Wellcome Foundation Ltd) which showed it to be serotype b. Beta-lactamase activity was shown by the method of McGhie et al. ${ }^{1}$ The minimal inhibitory concentration was tested by the agar dilution method of susceptibility testing, which is not critically dependent on the inoculum
(Adatah, Mast Laboratories Ltd). The minimum inhibitory concentration of chloramphenicol was $16 \mathrm{mg} / 1$ (control strain $<2.0 \mathrm{mg} / \mathrm{l}$ ) and that of ampicillin $32 \mathrm{mg} / \mathrm{l}$ (control strain $<1.0 \mathrm{mg} / \mathrm{l}$ ). All the other sensitivities were determined by routine antibiotic disc sensitivity testing (Mast Laboratories Ltd). The disc strength of cefuroxime was $30 \mu \mathrm{g}$.

\section{Comment}

Chloramphenicol-resistant, ampicillin-sensitive $H$ influenzae was first reported from the United States in $1972 .^{2}$ In 1977 a child in Oxfordshire survived meningitis caused by $H$ influenzae with the same antibiotic sensitivities. ${ }^{3}$ In 1979, however, $H$ influenzae type b resistant to both ampicillin and chloramphenicol caused an outbreak of meningitis in Bangkok in which three children died. ${ }^{4}$ In the same outbreak one child with $H$ influenzae type b meningitis was successfully treated with rifampicin and co-trimoxazole. The organism in our patient was sensitive to co-trimoxazole, and also to cefuroxime, which should be regarded as a therapeutic alternative when treating meningitis due to a similarly resistant organism as it penetrates adequately into the cerebrospinal fluid. ${ }^{5}$ If this strain of $H$ influenzae becomes more common the recommended antibiotic treatment for conditions such as epiglottitis and meningitis will have to be altered.

${ }^{1}$ McGhie D, Clarke P, Johnson T, Hutchinson JG. Detection of beta lactamase activity of Haemophilus influenzae. F Clin Pathol 1977;30:585. ${ }^{2}$ Barrett FF, Tabes LH, Morris CR, Stapleman WB, Clark DJ, Yow MD. A 12 year review of the antibiotic management of Haemophilus influenzae meningitis: comparison of ampicillin and conversion therapy including chloramphenicol. $\mathcal{F}$ Pediatr $1972 ; 81: 370-7$.

${ }^{3}$ Kinmonth A, Storrs CN, Mitchell RL. Meningitis due to chloramphenicol resistant Haemophilus influenzae type b. Br Med F 1978;i:694.

${ }^{4}$ Simasathien S, Duanzmani C, Echeverria P. Haemophilus influenzae resistant to ampicillin and chloramphenicol in an orphanage in Thailand. Lancet 1980;ii:1214-17.

5 Darnell R, Shepherd RH, Taylor JC, Firth JL. The use of cefuroxime in the treatment of meningitis and sepsis in the central nervous system. In : Wood C, Rue Y, eds. Cefuroxime update. London: Royal Society of Medicine, 1981. (International Congress and Symposium Series No 38.)

(Accepted 20 January 1982)

Alder Hey Children's Hospital, Liverpool L12 2AP

P MACMAHON, MB, MRCP, paediatric registrar

J SILLS, MB, MRCP, consultant paediatrician

E HALL, MB, FRCPATH, consultant pathologist

T FITZGERALD, FIMLS, chief medical laboratory scientific officer

\title{
Hypersensitivity to local anaesthetics: a direct challenge test with lignocaine for definitive diagnosis
}

Local anaesthetics hold a key position in medical and dental practice. When hypersensitivity (allergy) to them is suspected an accurate diagnosis must be established or a local anaesthetic found which the patient can take safely. Many tests have been advocated for this, but unfortunately, in-vitro tests have proved unreliable, and other procedures, such as nasal challenge and skin tests, have not been validated by controlled series. Indeed, in our own studies on skin testing with lignocaine a false-positive rate of one in four occurred among atopic subjects (unpublished observation).

We present here the details and results of a direct challenge test with lignocaine on eight patients with histories of hypersensitivity reactions attributable to this drug. Similar regimens have been reported ${ }^{2}$ but mainly to evaluate a suitable alternative local anaesthetic to that suspected as an allergen. In our regimen a solution of lignocaine was administered in saline without preservative or vasoconstrictor, thereby avoiding any possible contribution from these substances.

\section{Patients, methods, and results}

Seven women and one man (aged 18-56 years) were investigated after one or more suspected reactions to lignocaine with at least one of the following features: swelling of the lips and cheek, urticaria, wheeze, severe dyspnoea, 
hypotension, loss of consciousness, and times of onset varying between one minute and nine days. Investigations included history and general examination, prick skin tests with common allergens to determine atopic status, intradermal skin test with $0.2 \mathrm{ml} 1 / 1000$ lignocaine hydrochloride, and hospital admission for a direct challenge test.

\section{PREPARATION FOR CHALLENGE TEST}

Baseline observations of heart rate, blood pressure, and expiratory peak flow rate were recorded every 15 minutes for one hour and a blood sample taken.

Lignocaine injections were prepared from bottles of $1 \%$ and $2 \%$ plain lignocaine, free from preservative and vasoconstrictor. Dilutions of $1 / 10$ (1 $\mathrm{mg} / \mathrm{ml}), 1 / 100(0 \cdot 1 \mathrm{mg} / \mathrm{ml})$, and $1 / 1000(10 \mu \mathrm{g} / \mathrm{ml})$ were made from $1 \%$ lignocaine, labelled, and kept.

Chlorpheniramine $10 \mathrm{mg}$ intramuscularly was given to the patient.

Resuscitation agents were drawn up and placed by the patient's bed: adrenaline $1 / 1000$ ( $1 \mathrm{ml}$ for injection $\mathrm{im}$ ), chlorpheniramine $10 \mathrm{mg}$ ( $1 \mathrm{ml}$ for injection iv), and hydrocortisone $100 \mathrm{mg}$ ( $1 \mathrm{ml}$ for injection iv).

\section{CHALLENGE PROCEDURE}

The patient was attended by a nurse throughout the test and the ward doctor was within one minute's call for 30 minutes.

Lignocaine injections were given as follows (intervals between doses were 60 minutes for immediate or 24 hours for late reactions): (a) intradermal injection of $0.02 \mathrm{ml}$ at $1 / 1000$ dilution; $(b)$ subcutaneous injection of $0.05 \mathrm{ml}$ at $1 / 100$ dilution; (c) subcutaneous injection of $0.05 \mathrm{ml}$ at $1 / 10$ dilution; $(d)$ subcutaneous injection of $0.05 \mathrm{ml}$ undiluted $1 \%$ lignocaine; $(e)$ subcutaneous injection of $0.25 \mathrm{ml}$ undiluted $2 \%$ lignocaine; and $(f)$ subcutaneous injection of $2.0 \mathrm{ml}$ undiluted $2 \%$ lignocaine. If no reaction occurred the patient was allowed home with an escort one hour after the last injection unless the history indicated that a reaction could occur after several hours.

Emergency procedures were adopted if any reaction other than a local weal or flare developed: all further doses of lignocaine were stopped, further blood samples taken, and the patient attended constantly.

Results-Three patients were atopic and three had immune-related disorders (fibrosing alveolitis, recurrent urticaria, asthma with nasal polyps, and aspirin intolerance). Two of the atopic patients had positive reactions to skin tests with lignocaine (weal $\geqslant 4 \mathrm{~mm}$, flare $\geqslant 11 \mathrm{~mm}$ ). No patient showed any detectable reaction to the direct challenge.

\section{Comment}

In each of our eight cases it would be safe for the patient to receive plain lignocaine for further dental or aural or nasopharyngeal treatment. They have all now received such treatment without adverse reactions. Our regimen did not exclude the possibility that other components of the original formulation of the local anaesthetic could have provoked the presenting reaction. Multidose phials of lignocaine may contain methylparaben preservatives as well as a vasoconstrictor. These are known immunogens which may elicit both immediate and delayed hypersensitivity. ${ }^{3}{ }^{4}$ The toxic effects of vasoconstrictors and of lignocaine itself ${ }^{5}$ are well known. Although these factors could have been ruled out in our patients, we had excluded hypersensitivity to lignocaine itself and therefore saw little justification for further investigation.

As far as the question of the test's safety is concerned, the starting dose was extremely low $(0.2 \mu \mathrm{g})$; the presenting reactions had occurred with doses of $20-40 \mathrm{mg}$. This difference gives an adequate safety margin even if the patient is sensitised. Furthermore, our experience and published reports make us seriously doubt whether true anaphylaxis to lignocaine has ever been satisfactorily shown. Nevertheless, since this hypothesis can never be proved, every safety precaution must be taken during a direct challenge test with this drug. For practical purposes, the conclusion that our patients' presenting symptoms were not due to lignocaine hypersensitivity is adequate. As a precaution they have been advised not to receive any local anaesthetic preparation other than plain lignocaine, which is devoid of all preservatives and vasoconstrictors. We believe the benefits of the information gained from the direct challenge test far outweigh any potential risks.

Correspondence and requests for reprints should be addressed to: $\operatorname{Dr} M \mathbf{R}$ Barer, Department of Medical Microbiology, St George's Hospital Medical School, London SW17.

1 Incaudo G, Schatz M, Patterson R, Rosenburg M, Yammamoto S, Hamburger $\mathbf{R}$. Administration of local anaesthetics to patients with a history of prior adverse reaction. $\mathcal{F}$ Allergy Clin Immunol 1978;61 :33945.

2 de Shazo R, Nelson H. An approach to the patient with a history of local anaesthetic hypersensitivity: experience with 90 patients. $f$ Allergy Clin Immunol $1979 ; 63: 387-94$.

${ }^{3}$ Nagel JE, Fuscaldo JT, Fireman P. Paraben allergy. $\mathcal{F} A M A 1977 ; 237$ : 1594-5.

4 Adriani J. A review of the etiology and management of adverse reactions to local anaesthetics. Int Anaesthesiol Clin 1972;10:127-51.

5 Boakes AJ, Laurence DR, Lovel KW, O'Neil R, Verrill PJ. Adverse reactions to local anaesthetic/vasoconstrictor preparations. Br Dent $\mathcal{f} 1972$; 133 : 137-40.

(Accepted 26 fanuary 1982)

Asthma and Allergy Clinic, University College Hospital, London WC1

M R BARER, MB, BSC, house physician (now registrar, Department of Medical Microbiology, St George's Hospital Medical School, London SW 17)

M K MCALLEN, MD, FRCP, consultant physician (now senior research fellow, Department of Clinical Pharmacology, University College Hospital Medical School, London WC1)

\section{Endocrine pancreatic carcinoma and syndrome of inappropriate secretion of antidiuretic hormone}

Inappropriate secretion of antidiuretic hormone is a well-known complication in malignancy, especially in oat-cell carcinoma of the lung. The syndrome has also been reported in pancreatic adenocarcinoma ${ }^{1}$ but hitherto not in patients with an endocrine pancreatic tumour.

\section{Case history}

A 54-year-old man presented in 1979 with abdominal pain, weight loss, and an upper abdominal mass. At operation in October 1979 an inoperable tumour was found originating in the head of the pancreas and adherent to surrounding tissues. An excision biopsy specimen was taken.

Histological examination showed an undifferentiated monomorphous and highly vascular tumour with an organoid appearance. The densely packed tumour cells were of uniform size, and many mitotic figures were present (figure $(a)$ ). Aldehyde fuchsin staining yielded uniformly negative results, but Grimelius ${ }^{2}$ staining showed some areas with endocrine activity in tumour cells (figure (b)). Electron microscopy showed $\alpha$-like and $\delta$-like granules (figure $(c)$ ). Malignant pancreatic islet-cell tumour was diagnosed. Immunohistochemical stainings for insulin, glucagon, somatostatin, and antidiuretic hormone were negative.

Before and after operation the patient had hyponatraemia with a serum sodium concentration of $115 \mathrm{mmol}(\mathrm{mEq}) / \mathrm{l}$, serum osmolality of $243 \mathrm{mmo}$ $(\mathrm{mosmol}) / \mathrm{kg}$, and urine osmolality of $546 \mathrm{mmol} / \mathrm{kg}$. There were no clinical or laboratory signs of cardiac, pulmonary, neurological, renal, hepatic, or endocrine disease, and he received no medication.

After operation fasting concentrations of gastrin, glucagon, vasoactive intestinal peptide, insulin, somatostatin, and calcitonin were all within the normal range; the pancreatic polypeptide concentration was slightly raised (150 pmol/1; normal limit $100 \mathrm{pmol} / \mathrm{l})$. $\beta$-Human chorionic gonadotrophin was not found. Serum sodium concentration and osmolality returned to normal after intake of water was restricted to $1000 \mathrm{ml}$ daily.

Three months after operation, before starting treatment with streptozotocin, the patient was in fairly good clinical condition. With a water intake of $1000 \mathrm{ml}$ daily serum sodium concentration was $133 \mathrm{mmol} / 1$, serum osmolality $276 \mathrm{mmol} / \mathrm{kg}$, and urine osmolality $970 \mathrm{mmol} / \mathrm{kg}$. Plasma concentration of antidiuretic hormone, determined by radioimmunoassay, ${ }^{3}$ was $18 \mathrm{pg} / \mathrm{ml}$ (normally not exceeding $2 \mathrm{pg} / \mathrm{ml}$ if serum osmolality is less than 285 $\mathrm{mmol} / \mathrm{kg}^{3} \mathrm{4}^{4}$ ). After an oral water intake of $1400 \mathrm{ml}$ in 15 minutes serum sodium concentration fell to $126 \mathrm{mmol} / \mathrm{l}$ and serum osmolality to $260 \mathrm{mmol}$ / $\mathrm{kg}$; urine osmolality remained unchanged at around $900 \mathrm{mmol} / \mathrm{kg}$.

After four courses of streptozotocin $\left(500 \mathrm{mg} / \mathrm{m}^{2}\right.$ daily for five days every five weeks) a similar water intake caused adequate diuresis and no fall in serum osmolality. With a free water intake plasma concentration of antidiuretic hormone was within the normal range. During the treatment the size of the tumour decreased somewhat, as shown by echography.

\section{Comment}

Corrin et $a l^{5}$ described a patient with an oat-cell carcinoma of the pancreas of islet-cell origin and the syndrome of inappropriate secretion of antidiuretic hormone. Because of several interfering factors, however, they could not conclude that the syndrome was due to elaboration of vasopressin by the tumour. In our patient known 